\title{
Value of brain biopsy in neurodegenerative disease in childhood
}

\author{
E. BOLTSHAUSER and J. WILSON \\ From the Department of Neurology, The Hospital for Sick Children, London
}

\begin{abstract}
Boltshauser, E., and Wilson, J. (1976). Archives of Disease in Childhood, 51, 264. Value of brain biopsy in neurodegenerative disease in childhood. During the period 1968-1974, 45 children with suspected neurodegenerative syndromes underwent brain biopsy of the right frontal lobe. The histological examination was normal in $44 \%$ and nonspecifically abnormal in $43 \%$ of the specimens. In $13 \%$ a specific histological abnormality was found, namely 3 with spongy degeneration, 1 Alexander's leucodystrophy, 1 metachromatic leucodystrophy, and 1 pachygyria. Chemical analysis by thin-layer chromatography had little to offer in this series, being specifically abnormal only in the case of metachromatic leucodystrophy and nonspecifically abnormal in 6 cases. Postoperative generalized convulsions occurred in 3 children and a mild hemiparesis contralateral to the site of biopsy was noted in one patient.

Comparing the outcome of the group having histologically normal biopsies with the group having nonspecifically abnormal ones it is concluded that frontal biopsy is not of such high prognostic value as has been claimed in previous reports. Some flexibility in the choice of the biopsy site is suggested. The specimens should be examined by chemical analysis as well as electron microscope in addition to the routine histological and histochemical methods. The neurodegenerative disorders of childhood which are at present identifiable in life only by brain biopsy are listed.
\end{abstract}

Brain biopsy has been accepted for some time as a valuable means of investigating degenerative brain disease (Blackwood and Cumings, 1959, 1965; Cumings, 1965) but there have been very limited studies of its value in childhood (Bernard et al., 1966; Vigouroux et al., 1967; Henningsen and Klinken, 1971; Landing, Neustein, and Kamoshita, 1972). Moreover, many of the conditions thus formerly investigated, namely Batten's disease, Tay-Sachs disease, and metachromatic leucodystrophy, can now be more simply diagnosed either by enzymic assay or biopsy at less damaging sites (rectum, appendix, peripheral nerve, or skin). We think it appropriate therefore to review retrospectively experience of brain biopsy at the Hospital for Sick Children to provide a contemporary appraisal of the place of brain biopsy in the investigation of neurodegenerative disease in childhood. Biopsies of suspected tumours or herpes encephalitis are not included in this series.

Received 2 July 1975.

\section{Material and methods}

During the period 1968-1974, 45 children (22 boys, 23 girls) with suspected progressive neurological syndromes underwent brain biopsy. The patients' mean age was 3 years 9 months, range 4 months to 15 years. Age distribution is shown in the Fig. A biopsy was performed under general anaesthesia by a neurosurgeon after informed consent by both parents. Anterior to the right coronal suture a trephine disc of $2.4 \mathrm{~cm}$ diameter was removed. The dura was opened and a block of about $1 \mathrm{~cm}^{3}$ brain, including cortex and white matter, was obtained without use of diathermy. All biopsies were taken from the right frontal lobe, and one patient had an additional left frontal biopsy due to lack of white matter in the first specimen. Anticonvulsants and antibiotics were not routinely given after operation.

Half of the biopsy was used for lipid analysis by thin-layer chromatography of cortex and white matter separately. For conventional histological examination material was fixed in $4 \%$ formaldehyde, embedded in paraffin wax, and stained routinely with haematoxylin and eosin, van Gieson, and Mallory's PTAH stain, and frequently with luxol fast blue, solochrome cyanine, 


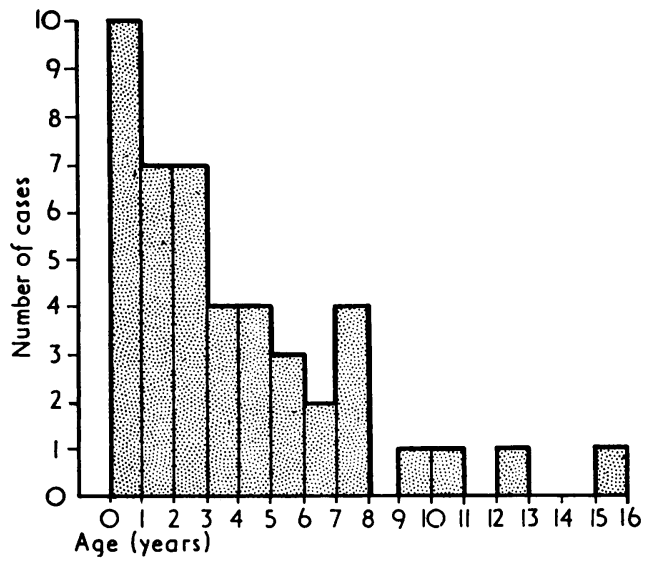

Fig.-Age distribution of 45 children who had brain biopsy.

and other stains as appropriate. For histochemical studies, material was frozen in hexane cooled to $-80^{\circ} \mathrm{C}$ in an acetone/carbon dioxide bath. Cryostat sections were stained by the following techniques: haematoxylin and eosin, celloidinized P.A.S., sudan black, oil red $O$, acid phosphatase, toluidine blue, luxol fast blue, Feyrter, and cresyl fast violet. Electron microscopy was rarely performed.

Case notes as well as all histological material from each patient were reviewed. Histological findings were classified into three groups; normal (including borderline changes), nonspecifically abnormal, and specifically abnormal. Follow-up information was available from 39 children. The outcome is known through later readmission, outpatient attendance, or correspondence with family doctors.

\section{Results}

Table I summarizes the histological findings of the 45 brain biopsies. The group with normal biopsies consisted of 11 boys and 9 girls with a mean age of 4 years 7 months. The group with

\section{TABLE I}

Summary of histological findings in 45 brain biopsies

\begin{tabular}{l|c}
\hline \multicolumn{1}{c|}{ Histology } & $\begin{array}{c}\text { No. of cases } \\
\text { (and \%) }\end{array}$ \\
\hline $\begin{array}{l}\text { Normal } \\
\text { Nonspecifically abnormal } \\
\text { Specifically abnormal }\end{array}$ & $20(44)$ \\
\hline Total & $19(43)$ \\
$6(13)$
\end{tabular}

nonspecifically abnormal histology included 8 boys and 11 girls, mean age 3 years 1 month; and that with specific abnormalities included 3 boys and 3 girls, mean age 3 years 4 months. Because the three groups were clinically very heterogeneous it is not appropriate to include here detailed clinical accounts, and only broad descriptions will be presented.

Histologically normal biopsies. In this group 10 children presented with clear evidence of progressive neurological syndromes including one child who may represent a variant of phenylketonuria (Smith, Clayton, and Wolff, 1975). 3 infants presented with severe developmental delay and in 7 patients there was doubtful evidence of neurological deterioriation.

Nonspecific histological abnormalities. In 4 children evidence of neurological regression was doubtful or lacking, 5 patients were severely oligophrenic, and 10 had convincing evidence of an evolving neurological syndrome. Among the latter a specific diagnosis could be established in 3 children at a later stage: Huntington's chorea, Addison-Schilder disease (adrenoleucodystrophy), and late-onset globoid cell leucodystrophy, respectively. The diagnosis in the third case was only established at necropsy, when globoid-cells, unequivocally lacking in the biopsy, were identified in a patchy distribution (Crome et al., 1973). This patient was investigated before the method for estimation of the enzyme galactocerebrosidase was introduced. The predominant histological findings in the nonspecifically abnormal biopsies are listed in Table II. No relation between the degree of histological abnormality and the clinical presentation or the outcome was found.

\section{TABLE II}

Predominant histological findings in 19 nonspecifically abnormal brain biopsies

\begin{tabular}{l|c}
\hline \multicolumn{1}{c|}{ Histology } & No. of cases \\
\hline Astrocytosis (white matter & 6 \\
$\quad$ and/or cortex) & 4 \\
Increased sudanophilic material & 3 \\
Astrocytosis plus increased & 2 \\
$\quad$ sudanophilic material & 4 \\
Astrocytosis and myelin loss & 19 \\
\hline increased sudanophilic material & \\
\hline Total & \\
\hline
\end{tabular}

Specific histological abnormalities. Table III lists the specifically abnormal histological findings with their corresponding chemical analysis. 
TABLE III

Histological findings in 6 specifically abnormal brain biopsies and their corresponding chemical analysis

\begin{tabular}{|c|c|}
\hline Histology & Chemistry \\
\hline $\begin{array}{l}\text { Spongy degeneration } \\
\text { Spongy degeneration } \\
\text { Spongy degeneration }\end{array}$ & $\begin{array}{l}\text { Normal } \\
\text { Normal } \\
\text { Cerebroside } \downarrow \\
\text { Sphingomyelin } \downarrow \text { (cortex) }\end{array}$ \\
\hline $\begin{array}{l}\text { Metachromatic } \\
\text { leucodystrophy }\end{array}$ & 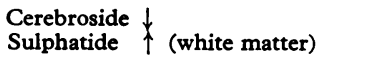 \\
\hline $\begin{array}{l}\text { Alexander's } \\
\text { leucodystrophy } \\
\text { Pachygyria }\end{array}$ & $\begin{array}{l}\text { Cerebroside } \\
\text { Cholesterol esters } \\
\text { Normal }\end{array}$ \\
\hline
\end{tabular}

Analytical studies. Among the 43 specimens investigated chemically the result was abnormal in 7. These findings are summarized in Table IV and compared with their corresponding histology. Only in the case of metachromatic leucodystrophy was neurochemical analysis diagnostically helpful; in all others, findings were nonspecific though in

TABLE IV

Findings in 7 brain biopsies with abnormal chemical analysis and their corresponding histology

\begin{tabular}{|c|c|}
\hline Chemistry & Histology \\
\hline $\begin{array}{l}\text { Cerebroside } \\
\text { Sphingomyelin } \downarrow \text { (cortex) }\end{array}$ & Spongy degeneration \\
\hline $\begin{array}{l}\text { Cerebroside } \\
\text { Cholesterol esters }\end{array}$ (white matter) & $\begin{array}{l}\text { Alexander's } \\
\text { leucodystrophy }\end{array}$ \\
\hline $\begin{array}{l}\text { Cerebroside } \downarrow \text { (white matter) } \\
\text { Sulphatide }\end{array}$ & $\begin{array}{l}\text { Metachromatic } \\
\text { leucodystrophy }\end{array}$ \\
\hline $\begin{array}{l}\text { Cerebroside } \\
\text { Cholesterol esters } \uparrow \text { (white matter) }\end{array}$ & $\begin{array}{l}\text { Astrocytosis, myelin loss, } \\
\text { increased sudanophilic } \\
\text { material }\end{array}$ \\
\hline $\begin{array}{l}\text { Cerebroside } \\
\text { Cholesterol esters }\end{array}$ (white matter) & $\begin{array}{l}\text { Astrocytosis, myelin loss, } \\
\text { increased sudanophilic } \\
\text { material }\end{array}$ \\
\hline $\begin{array}{r}\text { Cholesterol esters } \uparrow \text { (white matter } \\
\text { and cortex) }\end{array}$ & $\begin{array}{l}\text { Astrocytosis and myelin } \\
\text { loss }\end{array}$ \\
\hline 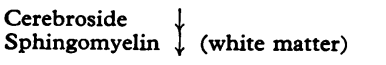 & Normal \\
\hline
\end{tabular}

the cases where demyelination was suggested by the presence of cholesterol esters conventional histology showed myelin loss. Table V summarizes the overall comparison of histological and chemical results.

Prognostic value. The clinical outcome has been compared in the groups with normal and with
TABLE V

Comparison of histological and chemical findings in 45 brain biopsies

\begin{tabular}{l|l|r}
\hline \multicolumn{1}{c|}{ Histology } & \multicolumn{1}{|c|}{ Chemistry } & No. of cases \\
\hline Normal & Normal & 17 \\
Normal & Not done & 2 \\
Normal & Abnormal & 1 \\
Abnormal & Normal & 19 \\
Abnormal & Abnormal & 6 \\
\hline Total & & 45 \\
\hline
\end{tabular}

nonspecifically abnormal histology (Table VI). The 3 patients with good evidence of improvement include 2 children with epilepsy whose previous deterioriation is now interpreted as due to prolonged but reversible minor status epilepticus. The third child's biopsy is compatible with recovery from a clinical illness suggestive of demyelination.

\section{TABLE VI}

Outcome of children who had histologically normal or nonspecifically abnormal brain biopsy

\begin{tabular}{l|c|c}
\hline \multicolumn{1}{c|}{ Outcome } & \multicolumn{2}{|c|}{ Histology } \\
\cline { 2 - 3 } & Normal & $\begin{array}{c}\text { Nonspecifically } \\
\text { abnormal }\end{array}$ \\
\hline No change & 7 & 7 \\
$\begin{array}{l}\text { Deterioriation } \\
\text { still alive } \\
\text { death }\end{array}$ & 2 & 2 \\
Improvement & 6 & 7 \\
Unknown & 3 & - \\
\hline Total & 2 & 19 \\
\hline
\end{tabular}

Complications. 3 children, one of whom had a history of epilepsy, suffered generalized grand mal fits postoperatively. The patient with metachromatic leucodystrophy had a mild leftsided hemiparesis which persisted in the postoperative period. A subgaleal cerebrospinal fluid collection occurred in one other child.

Correlation with other investigations. In the present series there is no correlation between cortical atrophy as suggested by widened sulci and pooling of air over the hemispheres in air encephalography and the histological findings. Half of the cases with evidence of cortical atrophy had a normal biopsy. In 7 children, in whom cerebrospinal fluid protein concentrations greater than $30 \mathrm{mg} / 100 \mathrm{ml}$ were found, brain biopsy was normal in 2 and nonspecifically abnormal in 3; the other 
patients suffered from metachromatic leucodystrophy and Alexander's disease, respectively.

\section{Discussion}

The proportion of only $13 \%$ of specifically abnormal brain biopsies might at first appear very low by contrast with earlier series (Blackwood and Cumings, 1965; Bernard et al., 1966; Landing et al., 1972) which have included up tc $40 \%$ of diagnostically helpful specimens. However, nearly all the conditions thus identified formerly are now recognized more simply and brain biopsy is no longer indicated. For example, during the period under review, at this hospital, 20 children with metachromatic leucodystrophy, 6 with Krabbe's globoid cell leucodystrophy, 42 with $\mathrm{GM}_{\mathrm{z}}$-gangliosidosis (35 with Tay-Sochs distase and 7 with late onset), and 51 with neuronal ceroid lipofuscinosis (Batten's disease) have been diagnosed without cerebral biopsy.

It appears, therefore, that the number of conditions in which brain biopsy is the diagnostic procedure of choice is very small and these may be suspected on clinical grounds. For example the diagnosis of spongy degeneration or Alexander's leucodystrophy, respectively, in 4 cases was suspected in view of an enlarging head associated with loss of skills or severe developmental delay. 2 of the cases with spongy degeneration had marked ventricular dilatation and increased intracranial pressure presumably due to basal cistern block, and the presence of obstructive hydroctphalus does therefore not exclude a neurodegenerative disorder. The finding of metachromasia in the biopsy of a 13-year-old boy with a long history of dementia whose motor nerve conduction velocity was within normal limits, was completely unexpected. Metachromatic material was present in the urine, but initially missed. This emphasizes that this reliable screening test has to be performed very carefully and should not be devalued by indiscriminate overuse. The finding of pachygyria, which cannot usually be shown neuroradiologically, was also unexpected.

Chemical analysis as presently applied appears to offer little help in obscure cases, but the accumulation of cholesterol esters may serve to confirm the presence of demyelination. Nevertheless, we think that chemical analysis should be performed routinely, otherwise exceptional findings such as a recently reported case of $\mathrm{GM}^{3}$-gangliosidosis would most likely be missed (Max et al., 1974).

Although in skilled hands brain biopsy is generally a safe procedure, we think that the only practical justification for what is essentially a damaging and potentially harmful procedure (Groves and Møller, 1966; Bubis, Goldhammer, and Braham, 1972) is if it assists with prognosis and genetic counselling. That such a small proportion of biopsies yields diagnostically valuable information for these purposes is somewhat disappointing. Moreover, though one might hope to be able to infer sufficient of the nature of the pathological process, namely its diffuseness and its continuing activity, to help in formulating prognosis without necessarily establishing the diagnosis in strict pathological terms (Wagner and Wisotzkey, 1963; Groves and Møller, 1966; Henningsen and Klinken, 1971), Table VI shows that of the $43 \%$ of biopsies with nonspecific changes, only about half showed continuing deterioriation afterwards. Conversely, a normal biopsy did not preclude a degenerative condition, since $40 \%$ of these children continued to deterioriate. Nor is it scientifically safe to assume, without animal transmission or tissueculture studies of isolated material, that a condition which is 'degenerative' clinically or histologically is invariably genetically determined.

The frequency of slow virus infections-apart from subacute sclerosing panencephalitis-as a cause of obscure progressive illness in childhood is not known, and it would therefore be valuable to undertake appropriate studies of biopsy material. It is unfortunate that no ultrastructural clues exist in the present series, since without electron microscope studies the presence of various forms of inclusion bodies and virus-like particles (Bubis et al., 1972), as well as mitochondrial abnormalities (Suzuki and Rapin, 1969; Sandbank and Lerman, 1972), would be missed. We would certainly advocate ultrastructural examination if not culture studies in future biopsies.

The site of the biopsy is obviously very important in processes with patchy distribution or uneven involvement of the cerebral lobes. This may account for the failure to recognize late-onset globoid-cell leucodystrophy (Crome et al., 1973). A later verified case of Krabbe's leucodystrophy with normal brain biopsy has been reported (Cumings, 1965). In a number of conditions, such as subacute sclerosing panencephalitis and demyelinating conditions, the disease process is more advanced in the occipital lobe (Blackwood, 1970; Ohya et al., 1974) and a frontal biopsy would usually be misleadingly normal. In some cases, particularly when cortical blindness is a feature, an occipital biopsy might be more helpful. The place of cerebellar biopsy has yet to be evaluated in neurodegenerative diseases.

Finally we have listed in Table VII the progressive 


\section{TABLE VII}

Neurodegenerative disorders of childhood which are at present identifiabie in life only by brain biopsy

Spongy degeneration

Alexander's leucodystrophy

Progressive myoclonus epilepsy (Lafora body type)

Infantile neuraxonal dystrophy

degenerative disorders of childhood which are at present identifiable in life only by brain biopsy. Pelizaeus-Merzbacher and Alper's diseases are intentionally omitted as they are clinically and pathologically ill-defined. We have included progressive myoclonus epilepsy (Lafora body type) because it is still very doubtful if Lafora body disease can be properly diagnosed on skeletal muscle biopsy. In some patients allegedly suffering from this condition, Lafora bodies have not been shown at all in the central nervous system (Neville, Brooke, and Austin, 1974; Carpenter et al., 1974); by contrast skeletal muscle was ultrastructurally normal in 2 sisters whose brain biopsy included Lafora bodies (Lope, Junguera, and Berenguel, 1974). Infantile neuraxonal dystrophy has been diagnosed on brain biopsy (Herman, Huttenlocher, and Bensch, 1969; Dooling, Schoene, and Richardson, 1974), but has also been missed in cases proven at necropsy (Haberland, Brunngraber, and Witting, 1972).

We thank Dr. Magda Erdohazi for generous help and advice in reviewing the histological material, and the consultants of the Hospital for Sick Children for permission to study patients under their care. Chemical analysis of the biopsies was performed at the National Hospital, Queen Square (Professor A. Davison). E.B. was supported by a grant from the Swiss National Foundation.

\section{REFERENCES}

Bernard, R., Vigouroux, R., Pinsard, N., Perrimond, H., Payan, H., Toga, M., and Dubois, D. (1966). Indications actuelles de la biopsie cérébrale chez l'enfant. Semaine des Hôpitaux de Paris, 42, 2104.

Blackwood, W. (1970). Cerebral biopsy. Handbook of Clinical Neurology. Vol. 10, Leucodystrophies and Poliodystrophies, p. 680. Ed. by P. I. Vincken and G. W. Bruyn. North-Holland, Amsterdam.

Blackwood, W., and Cumings, J. N. (1959). Diagnostic cortical biopsy. A histological and chemical study. Lancet, 2, 23.

Blackwood, W., and Cumings, J. N. (1965). The combined histological and chemical aspects of cerebral biopsies. Proceedings of the 5th International Congress of Neuropathology, Zurich, 1965, p. 364 . Excerpta Medica International Congress Series, No. 100. Excerpta Medica Foundation, Amsterdam.
Bubis, J. J., Goldhammer, Y., and Braham, J. (1972). Subacute spongiform encephalopathy. Electron microscopic studies, fournal of Neurology, Neurosurgery and Psychiatry, 35, 881.

Carpenter, S., Karpati, G., Andermann, F., Jacob, J. C., and Andermann, E. (1974). Lafora's disease: peroxisomal storage in skeletal muscle. Neurology, 24, 531.

Crome, L., Hanefeld, F., Patrick, D., and Wilson, J. (1973). Late onset globoid cell leucodystrophy. Brain, 96, 841.

Cumings, J. N. (1965). Some lipid diseases of the brain. Proceedings of the Royal Society of Medicine, 58, 21.

Dooling, E. C., Schoene, W. C., and Richardson, E. P. (1974). Hallervorden-Spatz syndrome. Archives of Neurology, 30, 70.

Groves, R., and Moller, J. (1966). The value of the cerebral cortical biopsy. Acta Neurologica Scandinavica, 42, 477.

Haberland, C., Brunngraber, E. G., and Witting, L. A. (1972). Infantile neuroaxonal dystrophy. Neuropathological and biochemical study of a case. Archives of Neurology, 26, 391.

Henningsen, G. J., and Klinken, L. (1971). Brain biopsy in selected cases of infantile psychosis. Acta Paedopsychiatrica, $38,90$.

Herman, M. M., Huttenlocher, P. R., and Bensch, K. G. (1969). Electron microscopic observations in infantile neuroaxonal dystrophy. Archives of Neurology, 20, 19.

Landing, B. H., Neustein, H. B., and Kamoshita, S. (1972). Biopsy diagnosis of lipidoses: background considerations, general concepts and practical aspects. Advances in Experimental Medicine and Biology. Vol. 19, Sphingolipids, Sphingolipidoses and Allied Disorders, p. 15 . Ed. by B. W. Volk and S. M. Aronson. Plenum Press, New York and London.

Lope, E. S., Junguera, S., and Berenguel, A. B. (1974). Progressive myoclonic epilepsy with Lafora's bodies. Acta Neurologica Scandinavica, 50, 537.

Max, S. R., Maclaren, N. K., Brady, R. O, Bradley, R. M., Rennels, M. B., Tanaka, J., Garcia, J. H., and Cornblath, M. (1974). $\mathrm{GM}_{3}$ (hematoside) sphingolipodystrophy. New England fournal of Medicine, 291, 929.

Neville, H. E., Brooke, M. H., and Austin, J. H. (1974). Studies in myoclonus epilepsy (Lafora body form). IV. Skeletal muscle abnormalities. Archives of Neurology, 30, 466.

Ohya, T., Martinez, A. J., Jabbour, J. T., Lemmi, H., and Duenas, D. A. (1974). Subacute sclerosing panencephalitis. Correlation of clinical, neurophysiologic and neuropathologic findings. Neurology, 24, 211.

Sandbank, U., and Lerman, P. (1972). Progressive cerebral poliodystrophy-Alper's disease. Disorganized giant neuronal mitochondria on electron microscopy. Fournal of Neurology, Neurosurgery and Psychiatry, 35, 749.

Smith, I., Clayton, B. E., and Wolff, O. H. (1975). New variant of phenylketonuria with progressive neurological illness unresponsive to phenylalanine restriction. Lancet, 1, 1108.

Suzuki, K., and Rapin, I. (1969). Giant neuronal mitochondria in an infant with microcephaly and seizure disorder. Archives of Neurology, 20, 62.

Vigouroux, R. P., Toga, M., Choux, M., Baurand, C., Dubois, D., and Perrimond, H. (1967). Intérêt de la biopsie cérébrale chez l'enfant dans les affections cérébrales chroniques. Neurochirurgie, 13, 385.

Wagner, J. A., and Wisotzkey, H. (1963). Cerebral cortical biopsy: a new vista for the pathologist. Southern Medical fournal, 56, 415.

Correspondence to Dr. E. Boltshauser, UniversitätsKinderklinik Kinderspital, Steinweisstrasse 75, CH8032, Zurich, Switzerland. 